\title{
Hubungan Antara Pola Asuh Orang Tua dengan Hasil Belajar IPA Siswa Kelas V
}

\author{
Ni Luh Widiantari ${ }^{1}$, I Made Suarjana ${ }^{2}$ \\ ${ }^{12}$ Prodi Pendidikan Guru Sekolah Dasar, Universitas Pendidikan Ganesha,Singaraja, \\ Indonesia \\ e-mail: luh.widiantari@undiksha.ac.id, imade.suarjana@undiksha.ac.id
}

\begin{abstract}
Abstrak
Hasil belajar IPA siswa kelas $\mathrm{V}$ lebih rendah dari KKM dan pekerjaan orang tua siswa sebagaian besar sebagai wiraswasta. Permasalahan dalam kehidupan sehari-hari selalu berhubungan dengan IPA. Oleh karena itu, penelitian bertujuan untuk mengetahui hubungan antara pola asuh orang tua dengan hasil belajar IPA siswa kelas V. Jenis penelitian ini adalah penelitian ex post facto. Populasi penelitian berjumlah 134 orang. Sampel penelitian ini berjumlah 113 orang siswa yang diambil dengan teknik proporsional random sampling. Data pola asuh orang tua dikumpulkan melalui pengisian angket, sedangkan data hasil belajar IPA siswa diperoleh melalui pencatatan dokumen. Teknik analisis data yang digunakan dalam penelitian ini adalah teknik analisis deskriptif dan teknik analisis inferensial. Hasil penelitian menunjukkan bahwa terdapat hubungan antara pola asuh orang tua dengan hasil belajar IPA siswa kelas $\mathrm{V}$ yang ditunjukkan dengan koefisien korelasi $R$ sebesar 0,96 yang artinya antara pola asuh orang tua memiliki hubungan yang sangat kuat dengan hasil belajar IPA siswa Kelas V. Pola asuh yang positif atau menerima akan memiliki pengaruh yang baik, sehingga pola asuh ini dapat mendukung dan memacu peningkatan hasil belajar.
\end{abstract}

Kata kunci: Hasil Belajar IPA, Pola Asuh Orang Tua

\begin{abstract}
The learning outcomes of science students in class $V$ are lower than KKM and most parents work as entrepreneurs. Problems in everyday life are always related to science. This research aimed to determine the relationship between parenting styles and science learning outcomes of fifth-grade. The type of the research was ex post facto research. The research population which amounted to 134 people. The sample in this research amounted to 113 people taken with proportional random sampling technique. The data of parenting styles were collected by questionnaire method, while the data of science learning outcomes students obtained through document analyse. Data analyse technique used statistic descriptive technique and statistic inferential technique. The result showed is a relationship relationship between parenting styles and science learning outcomes of fifth-grade indicated with 0,96 $R$ correlation coefficient which means parenting style it has very strong relationship with science learning outcomes of fifth-grade. Positive or accepting parenting will have a good influence, so this parenting can support and spur increased learning outcomes.
\end{abstract}

Keyword: parenting styles, science learning outcomes

\footnotetext{
*Corresponding author.

Received 20 April 2020, Accepted 20 Juni 2020; Available online 5 Juli 2020 (C) 2020 MI All Rights Reserved
} 


\section{Pendahuluan}

Pendidikan dapat dijadikan sebagai sarana untuk melahirkan sumber daya manusia yang berkualitas dan mampu bertahan dan bersaing di era globalisasi saat ini. Pendidikan mampu mengubah pola pikir seseorang untuk mewujudkan segala impian yang dimilikinya, sehingga manusia mampu mengikuti perkembangan zaman. Pendidikan bertujuan untuk menyiapkan generasi penerus bangsa yang berkualitas, bertanggungjawab dan memiliki keterampilan. Untuk mencapai tujuan tersebut, suatu hal yang dapat dilakukan adalah memperkuat aktivitas belajar baik itu pendidikan formal maupun nonformal.

Suatu pendidikan tidak terlepas dari kata belajar. Belajar merupakan salah satu aktivitas belajar yang ditandai dengan adanya stimulus dan respon dan tidak dapat di pisahkan dari proses pendidikan. Belajar didefinisikan sebagai segala usaha yang dilakukan seseorang dan menyangkut aspek-aspek kognitif, afektif dan psikomotorik dalam mecapai tujuan tertentu. Usman (dalam Nurhamidah, dkk 2019) menyatakan bahwa hasil belajar berkaitan dengan perubahan yang terjadi pada aspek kognitif, afektif dan psikomotor.

Keberhasilan dalam proses belajar dapat diketahui berdasarkan hasil belajar yang diperoleh di sekolah. Hasil belajar adalah hasil dari kegiatan proses belajar mengajar dengan adanya perubahan tingkah laku. Menurut Nawawi (dalam Susanto, 2013) menyatakan hasil belajar adalah tingkat keberhasilan siswa di sekolah yang dinyatakan berupa skor dari hasil tes mata pelajaran tertentu. Ada 2 faktor yang mempengaruhi hasil belajar siswa yaitu faktor internal dan faktor eksternal. faktor internal merupakan faktor yang berasal dari dalam diri peserta didik, misalnya minat, kecerdasan, sikap, ketekunan dan kesehatan. Sedangkan faktor eksternal merupakan faktor yang berasal dari luar diri peserta didik yaitu keluarga, sekolah dan masyarakat. Sehingga faktor eksternal yang berpengaruh terhadap hasil belajar adalah pola asuh orang tua, tempat tinggal, dan status ekonomi (Santi, 2019).

Faktor eksternal dari hasil belajar berkaitan dengan Tri Pusat Pendidikan. Tri Pusat Pendidikan di cetuskan oleh Ki Hajar Dewantara. Tri Pusat Pendidikan merupakan pendidikan yang dilaksanakan dalam tiga lingkungan berbeda dan saling berkaitan satu sama lain. Tri Pusat Pendidikan merupakan pendidikan yang dilakukan oleh tiga pihak secara berhubungan dan saling berkaitan satu sama lain yaitu keluarga, sekolah dan masyarakat.

Keluarga adalah perkumpulan individu yang terdiri dari ayah, Ibu dan anak yang berkumpul dalam suatu tempat tinggal dalam keadaan yang saling bergantungan satu sama lain. Keluarga adalah proses sosialisasi pertama mulai anak dilahirkan hingga menuju proses pendewasaan anak sehingga mempelajari kebiasaan, sikap, norma-norma, dan tingkah laku (Anggraini, 2017)

Pendidikan keluarga adalah kewajiban orang tua untuk membimbing, mengarahkan dan mendidik anaknya. Di dalam keluarga anak akan mendapatkan pendidikan agama, bahasa, etika, dan pendidikan moral. Semuanya dilaksanakan dalam kehidupan sehari-hari mulai dari belajar berbicara, merangkak, hingga belajar berjalan dan beranjak dewasa. Orang tua hendaknya memberikan pengalaman-pengalaman yang bermakna. Pengalaman anak di lingkungan keluarga akan memberikan kesan yang melekat dalam diri anak sehingga terpancar dari prilaku interaksinya dengan lingkungan, sehingga orang tua dapat dikatakan sebagai penanggung jawab pendidikan yang pertama dan utama.

Pendidikan keluarga menjadi landasan atau dasar pengalaman anak karena sebelum anak-anak terjun ke lingkungan sekolah dia harus mengetahui terlebih dahulu lingkungan keluarganya sendiri. Hasil dari pendidikan di keluarga akan di implementasikan di kehidupan sekolah maupun di kehidupan masyarakat. Keluarga berfungsi untuk meneruskan nilai, keyakinan, sikap, pengetahuan dan keterampilan. Hubungan orang tua dengan anak berhubungan dengan perkembangan kognitif, emosional dan sosial. Setiap orang tua memiliki berbagai cara dalam mengasuh, mendidik dan membimbing anak menuju proses pendewasaan. Hubungan yang baik akan memiliki pengaruh baik terhadap perkembangan anak dalam penyesuaian diri, kesejahteraan, perilaku sosial, dan menyalurkan nilai. Apabila 
kualitas hubungan yang buruk akan berpengaruh buruk terhadap perkembangan anak (Lestari, 2012).

Fenomena pola asuh orang tua yang bervariasi akan menimbulkan dampak yang berbeda dalam setiap keluarga. Cara pengasuhan orang tua pastinya akan berbeda-beda karena pola asuh orang tua berkaitan tentang cerminan perilaku orang tua saat berinteraksi kepada anaknya. Fitasari (2019) menyatakan bahwa pola asuh orang tua adalah upaya yang dilakukan oleh orang tua dalam menjaga dan membimbing anak sejak dilahirkan hingga menuju proses pendewasaan diri. (Pucangan, 2017) menyatakan bahwa pola asuh orang tua adalah suatu cara yang diterapkan oleh orang tua untuk menjaga, merawat dan mendidik anak dengan membentuk interaksi yang bertujuan untuk membangun kepribadian anak, kecerdasan emosional anak, membentuk watak, serta memenuhi kebutuhan fisik dan non fisik. Pola asuh orang tua adalah cara yang dilakukan orang tua dalam membimbing dan mendidik anak sehingga anak dapat tumbuh menjadi seorang yang memiliki perilaku sesuai dengan norma-norma yang berlaku di masyarakat (Widhiasih, 2017).

Pengasuhan dan sikap orang tua memiliki pengaruh terhadap perkembangan anak karena anak-anak akan meniru dari lingkungan terdekatnya, karena itu pola asuh merupakan hal yang mendasar dalam mendorong anak untuk mau belajar sehingga mencapai hasil yang memuaskan (Juniarti, 2020). Orang tua menjadi faktor terbesar yang menentukan sikap, perkembangan kognitif dan kondisi psikologis anak, semakin anak kehilangan sosok orang tuanya maka semakin besar kemungkinan anak kehilangan arah hidupnya (Susanto, 2019). Amir (2019:38) menyatakan bahwa pola pengasuhan yang diterapkan dapat memacu semangat anak dalam belajar karena orang tua akan memberikan dorongan (support), mengarahkan (parental control) dan ketegasan (power). Sehingga pola pengasuh yang tepat akan mampu meningkatkan hasil belajar anak yang optimal (Sugiartini, 2017).

Rohner (dalam Wibowo, 2012) menyimpulkan bahwa pengalaman yang didapat saat masa kecil seseorang sangat memengaruhi kepribadian yang dimiliki. Penelitian yang menggunakan teori PAR (Parental Acceptance- Rejection Theory) menyimpulkan bahwa pola asuh orang tua dibagi menjadi dua yaitu, pola asuh menerima (acceptance) dan pola asuh menolak (rejection), akan memengaruhi perkembangan prilaku, sosial, emosi, kesehatan, dan perkembangan kognitif.

Berdasarkan observasi dan wawancara dengan guru-guru di SDN gugus II kecamatan Tembuku pada tanggal 25-28 Oktober 2019 yang terdiri dari 7 sekolah dasar dengan jumlah seluruh siswa yaitu 134 orang terdapat 73 siswa yang belum mencapai KKM Permasalahan dalam kehidupan sehari-hari selalu berhubungan dengan IPA. IImu Pengetahuan Alam merupakan salah satu mata pelajaran di jenjang sekolah dasar yang membahas tentang peristiwa-peristiwa yang terjadi di alam. IImu Pengetahuan Alam diharapkan dapat memberikan pelajaran tentang diri sendiri dan alam sekitarnya. Pembelajaran IPA memiliki peran penting bagi siswa karena IPA di perlukan dalam kehidupan sehari-hari melalui pemecahan masalah yang dapat diselesaikan (Agustiana dan Tika, 2013). Hasil dari belajar IPA adalah hasil perubahan tingkah laku siswa berdasarkan indikator ketercapaian tujuan belajar IPA melalui pengalaman belajar dalam bidang IPA (Fithah, 2011).

Selain hasil belajar IPA yang rendah, pekerjaan orang tua peserta didik mayoritas bekerja sebagai buruh dan wiraswasta. Orang tua yang memiliki pekerjaan sebagai buruh dan wiraswasta, cenderung lebih fokus kepada pekerjaannya untuk memenuhi persaingan dalam dunia usaha. Akibatnya orang tua akan mengalami kekurangan waktu bersama anakanaknya. Pada dasarnya anak-anak yang malas belajar tentunya tidak akan mau belajar apabila tidak didampingi atau dibimbing oleh orang tua. Hal seperti ini akan memengaruhi hasil belajar yang diraih di sekolah karena pekerjaan akan menjadi penghalang kedekatan orang tua dengan anak. Oleh karena itu, pola asuh yang diterapkan akan menentukan keberhasilan anak dalam dunia pendidikan dari anak tersebut (Wibowo, 2012).

Berdasarkan uraian diatas dan masalah yang muncul maka dipandang perlu untuk meneliti adanya hubungan antara pola asuh orang tua dengan hasil belajar IPA siswa sebagaimana belum pernah dilakukan penelitian yang sejenis di SDN Gugus II Kecamatan 
Tembuku. Oleh karena itu perlu melakukan penelitian yang berjudul "Hubungan Antara Pola Asuh Orang Tua dengan Hasil Belajar IPA Siswa Kelas V SDN Gugus II Kecamatan Tembuku Tahun Pelajaran 2019/2020".

Tujuan dari penelitian ini adalah untuk mengetahui hubungan antara pola asuh orang tua dengan hasil belajar IPA siswa di Kelas V SDN Gugus II Kecamatan Tembuku Tahun Pelajaran 2019/2020.

\section{Metode}

Penelitian ini pada dasarnya bertujuan untuk mengetahui hubungan antara pola asuh orang tua dengan hasil belajar IPA, dengan tidak memanipulasi variabel bebas atau menggali fakta yang sudah terjadi sebelumnya sehingga penelitian ini tergolong penelitian ex post facto.

Penelitian ini dilaksanakan di SDN Gugus II Kecamatan Tembuku pada semester genap 2019/2020 dengan jumlah sekolah sebanyak 7 sekolah dasar yaitu SDN 1 Tembuku, SDN 2 Tembuku, SDN 3 Tembuku, SDN 4 Tembuku, SDN 1 Undisan, SDN 2 Undisan dan SDN 3 Yangapi.

Populasi dalam penelitian ini adalah adalah seluruh siswa kelas V SDN Gugus II Kecamatan Tembuku Tahun Pelajaran 2019/2020 yang terdiri dari 134 orang siswa dengan jumlah sampel sebanyak 113 siswa. Pengambilan sampel menggunakan tektik proporsional random sampling yang mengacu pada tabel R.V. Krecjie and D.W. Morgan. Proporsional random sampling adalah teknik menentukan sampel dengan menyeleksi jumlah populasi sesuai dengan ukuran unit sampling.

Dalam penelitian ini terdapat dua variabel yaitu variabel bebas dan variabel terikat. Variabel bebas dalam penelitian ini adalah pola asuh orang tua $(X)$ sedangkan variabel terikat dalam penelitian ini adalah hasil belajar IPA (Y).

Data yang diperoleh dapat dikumpulkan melalui metode nontes. Metode yang digunakan untuk mengumpulkan data hasil belajar IPA siswa yaitu menggunakan metode pencatatan dokumen. Sedangkan tentang pola asuh oran tua yaitu dengan menggunakan kuesioner/angket. Penelitian ini menggunakan teori PAR (Parental Acceptance- Rejection Theory) menyimpulkan bahwa pola asuh orang tua dibagi menjadi dua yaitu, pola asuh menerima (acceptance) dan pola asuh menolak (rejection). Indikator pola asuh acceptance (menerima) yaitu memberikan waktu luang bersama dengan anak dalam berbagai kegiatan, menghargai anak, menjalin komunikasi yang hangat dan terbuka dengan anak, memperhatikan kebutuhan anak dan bersikap terbuka dengan anak. Indikator pola asuh rejection (menolak) yaitu menuntuk anak secara berlebih, tidak memperdulikan anak, dominasi pada anak, menunjukkan sikap tidak mencintai anak dan sering memberi hukuman verbal atau fisik.

Jenis kuesioner yang digunakan dalam penelitian ini adalah jenis kuesioner tertutup, pada lembar sudah disediakan pilihan jawaban sehingga kuesioner tertutup menggunakan skala Likert sebagai acuan untuk menyediakan jawaban.

Instrumen penelitian yang telah disusun berdasarkan kisi-kisi harus diuji kelayakan (valid) instrumen tersebut dengan uji validitas dan uji reliabilitas. Berdasarkan hasil perhitungan uji validitas isi instrument pola asuh orang tua dapat di simpulkan bahwa instrumen pola asuh orang tua memenuhi kriteria validitas isi kategori validitas isi sangat tinggi. Berdasarkan hasil uji coba 30 butir item instrumen pada 50 responden dan hasil perhitungan dengan Microsoft Office excel terdapat 5 butir instrumen yang tidak valid sehingga tidak dapat digunakan dalam penelitian. Selanjutnya 25 butir item yang telah valid diuji reliabilitas dengan menggunakan rumus Alpha Cronbach sehingga 25 butir item memiliki kategori reliabilitas tinggi dan layak digunakan untuk penelitian.

Metode analisis data yang digunakan dalam penelitian ini adalah metode analisis deskriptif dan metode analisis infrensial. Uji prasyarat analisis yang digunakan yaitu uji normalitas dan uji linieritas. Uji normalitas dihitung dengan menggunakan rumus Chi-Square 
bertujuan untuk menentukan apakah data yang diperoleh dapat diuji dengan statistik atau tidak. Sedangkan Uji linieritas digunakan untuk mengetahui hubungan antara variabel bebas dengan variabel terikat. Pengujian normalitas dihitung dengan berbantuan SPSS Setelah uji prasyarat terpenuhi maka dilanjutkan ke uji hipotesis dengan menggunakan analisis regresi sederhana (product moment).

\section{Hasil dan Pembahasan}

Setelah analisis deskriptif dilakukan, didapatkan deskripsi data pola asuh orang tua dan data hasil belajar IPA yang disajikan pada Tabel 1.

Tabel 1

Deskripsi data pola asuh orang tua dan hasil belajar IPA

\begin{tabular}{ccccccc}
\hline No & Nilai Minimum & $\begin{array}{c}\text { Nilai } \\
\text { Maksimum }\end{array}$ & Mean & Median & Modus & $\begin{array}{c}\text { Standar } \\
\text { Deviasi }\end{array}$ \\
\hline 1 & 67 & 90 & 80 & 80,16 & 79,58 & 6,66 \\
2 & 70 & 96 & 83,80 & 84,61 & 87,87 & 6,72 \\
\hline
\end{tabular}

Pengujian asumsi digunakan untuk menguji apakah data yang didapatkan memenuhi prasyaratan dengan teknik yang telah ditetapkan. Uji prasyarat analisis yang digunakan yaitu uji normalitas sebaran data, uji linieritas, dan uji hipotesis. Uji normalitas pada penelitian ini disajikan pada Tabel 2.

Tabel 2

Rekapitulasi Hasil Uji Normalitas Sebaran Data Pola Asuh Orang Tua dan Hasil Belajar IPA

\begin{tabular}{cccc}
\hline Variabel & Chi-Square tabel & Chi-Square hasil & Keterangan \\
\hline $\mathrm{X}$ & 137.701 & 10,79 & Normal \\
$\mathrm{Y}$ & 137.701 & 7,18 & Normal \\
\hline
\end{tabular}

Tabel 2 menunjukkan nilai harga Chi-Square hasil lebih kecil dari harga Chi-Square tabel, maka dapat disimpulkan hasil belajar IImu Pengetahuan alam siswa berdistribusi normal.

Uji linieritas berfungsi untuk mengetahui hubungan dua variabel tersebut linier atau tidak. Berdasarkan analisis yang dilakukan dengan berbantuan SPSS, diperoleh signifikansi linearity sebesar $0.000(p<0.05)$ sehingga pola asuh orang tua dengan hasil belajar IPA memiliki hubungan yang linier. Sedangkan signifikanis Deviation From Linearity sebesar 0.068 ( $p>0.05$ ) sehingga pola asuh orang tua dengan hasil belajar IPA memiliki hubungan yang berarti.

Setelah uji prasyarat analisis terpenuhi, selanjutnya dilakukan uji hipotesis penelitian. Pengujian hipotesis menggunakan analisis product moment untuk mengetahui signifikan korelasi antara pola asuh orang tua dengan hasil belajar IPA. Besarnya nilai $r$ tabel dapat diperoleh dengan derajat kebebasan $(\mathrm{df}=\mathrm{N}-2)$, pada taraf signifikansi $5 \%$ dan diperoleh $\mathrm{df}=$ 113-2=111 dan diperoleh $r$ tabel sebesar 0.1848, dikarenakan $r$ hitung $0.960>r$ tabel 0.1848 , maka dapat dinyatakan terdapat hubungan yang signifikan antara pola asuh orang tua dengan hasil belajar IPA siswa Kelas V SDN Gugus II Kecamatan Tembuku Tahun Pelajaran 2019/2020. Hasil penelitian ini mendukung teori (Wibowo, 2012) yang menyatakan bahwa pola asuh yang diterapkan orang tua kepada anaknya akan menentukan keberhasilan anak dalam dunia Pendidikan. Hasil penelitian ini sejalan dengan penelitian yang dipaparkan pada kajian hasil penelitian yang relevan, yaitu penelitian yang dilakukan oleh Sugiartini (2017) berjudul "Hubungan Pola Asuh Orang Tua dan Rasa Percaya Diri Terhadap Hasil Belajar IPA Kelas V" yang menyimpulkan bahwa penelitian menunjukkan terdapat hubungan yang positif dan signifikan antara pola asuh orang tua terhadap hasil 
belajar IPA siswa kelas V SD di Gugus VIII Desa Seraya dengan koefisien korelasi R sebesar 0,395 . Dengan penerapan pola asuh yang tepat atau dapat dikatakan pola pengasuh yang baik sehingga mampu meningkatkan hasil belajar anak secara optimal.

Penelitian lain yang dilakukan oleh Budang (2017) berjudul "Korelasi Pola Asuh Orang Tua dengan Hasil Belajar Matematika Pada Siswa Kelas IV SD Negeri 5 Tengadak" yang menyimpulkan bahwa terdapat hubungan yang positif dan signifikan pola asuh orang tua dengan hasil belajar matematika siswa kelas IV SDN 5 Tengadak tahun pelajaran 2016/2017. Berdasarkan hasil penelitian maka dapat disimpulkan bahwa orang tua adalah faktor yang sangat penting dalam menentukan tinggi rendahnya hasil belajar anak di sekolah. Pengasuhan dan sikap orang tua sangat dibutuhkan bagi perkembangan anak karena anak-anak akan meniru dari lingkungan terdekatnya, karena itu pola asuh adalah hal yang mendasar dalam mendorong anak untuk mau belajar sehingga mencapai hasil yang memuaskan (Juniarti, 2020).

Hasil perhitungan koefisien determinasi sebesar $92 \%$ yang artinya variabel pola asuh orang tua $(X)$ secara simultan berpengaruh terhadap variabel hasil belajar IPA siswa Kelas $V$ SDN Gugus II Kecamatan Tembuku Tahun Pelajaran 2019/2020 (Y) sedangkan 8\% dipengaruhi oleh variabel lain. Berdasarkan perhitungan hasil kuesioner didapatkan jenis pola asuh acceptance (menerima) lebih tinggi yaitu dengan rata-rata sebesar 61 (98 orang) sedangkan pola asuh rejection (menolak) dengan rata-rata sebesar 42 (12 orang). Berdasarkan hasil rata-rata tersebut maka orang tua siswa kelas V SDN Gugus II Kecamatan Tahun Pelajaran 2019/2020 cenderung menerapkan pola asuh acceptance (menerima) dibandingkan dengan pola asuh rejection (menolak).

Untuk mengetahui seberapa besar koefisien korelasi, maka nilai $r_{x y}$ dibandingkan dengan tingkat korelai dan kekuatan hubungan sehingga pola asuh orang tua memiliki hubungan yang sangat kuat dengan hasil belajar IPA siswa Kelas V SDN Gugus II Kecamatan Tembuku Tahun Pelajaran 2019/2020.

Penelitian ini berkaitan dengan faktor eksternal yang memengaruhi hasil belajar adalah pola asuh orang tua, tempat tinggal, dan status ekonomi (Santi, 2019). Berdasarkan faktor eksternal yang memengaruhi hasil belajar maka pola asuh yang diterapkan orang tua dapat memacu keberhasilan anak dalam pendidikan karena ada unsur-unsur sebagai berikut: a) orang tua akan memberikan dorongan (support); b) mengarahkan (parental control); c) tindakan yang mencerminkan ketegasan (power) Amir (2019:38). Pengasuhan yang baik adalah orang tua yang selalu siap mendampingi, memberikan dorongan, dan teguran kepada anak karena besarnya niat anak dalam belajar tidak terlepas dari dorongan orang tua. Oleh karena itu, orang tua seharusnya lebih teliti dalam mengasuh anak dan menerapkan pola asuh yang tepat karena orang tua memiliki tanggung jawab dalam menjaga, mengarahkan, membimbing, mendidik dan mengawasi pergaulan anak agar memiliki perkembangan intelektual yang tinggi.

Bersadarkan hasil penelitian, keluarga merupakan kelompok sosial pertama yang menjadi pusat untuk mengenalkan segala jenis nilai-nilai kehidupan. Pola asuh orang tua adalah upaya orang tua dalam menjaga dan membimbing anak dari sejak dilahirkan hingga menuju proses pendewasaan diri. Oleh karena itu hubungan orang tua dengan anak harus dipelihara sejak dini. Hubungan baik dengan anak akan berpengaruh positif bagi perkembangan anak, misalnya dalam penyesuaian diri, perilaku sosial, dan menyalurkan nilai-nilai yang ada dalam keluarga. Pola asuh yang diterapkan orang tua kepada anaknya akan menentukan keberhasilan anak dalam dunia pendidikan.

Pembelajaran IPA di SD adalah suatu mata pelajaran yang sangat berperan penting, dengan pembelajaran IPA siswa tidak hanya mendapatkan sebuah pengetahuan tentang IPA, namun siswa juga mendapatkan nilai-nilai yang akan membentuk kepribadian manusia yang baik, rasa ingin tahu yang tinggi, dan berkarakter melalui pengalaman langsung yang dialami oleh peserta didik itu sendiri.

Hubungan yang erat dan hangat antara orang tua dan anak maka berpotensi kecil munculnya tindakan buruk karena masalah yang dimiliki oleh anak baik di lingkungan 
sekolah maupun di luar sekolah dapat diatasi dengan baik dalam interaksi keluarga. Pola asuh yang baik akan dapat memacu keberhasilan anak dalam bidang akademik dengan cara memberikan motivasi agar anak semangat dalam belajar. Penerapan pola asuh yang tepat juga dapat menjadikan anak berkepribadian yang seimbang, berani dalam mengambil keputusan, memiliki rasa percaya diri, dan bahagia secara psikologis. Komunikasi antara orang tua dan anak akan terjalin dengan baik sehingga anak terbuka saat mengalami masalah. Penerapan pola asuh yang positif atau menerima seperti memperhatikan anak, memberikan waktu luang, dan tidak menuntut secara berlebihan, maka anak tersebut akan merasa disayangi, dilindungi, dan diberi dukungan oleh orang tuanya, sehingga pola asuh ini dapat mendukung dan memacu peningkatan hasil belajar anak.

\section{Simpulan}

Berdasarkan hasil penelitian dan pembahasan dapat dikemukakan simpulan yakni terdapat hubungan yang signifikan antara pola asuh orang tua dengan hasil belajar IPA siswa kelas V. Berdasarkan tabel koefisien korelasi dapat disimpulkan bahwa hubungan antara pola asuh orang tua memiliki hubungan yang sangat kuat dengan hasil belajar IPA siswa Kelas V SDN Gugus II Kecamatan Tembuku Tahun Pelajaran 2019/2020. Hal ini dapat diartikan bahwa penerapan pola asuh yang tepat akan berpengaruh terhadap tingginya hasil belajar IPA di sekolah. Berdasarkan hasil penelitian ini, maka dapat diajukan beberapa saran sebagai berikut. (1) Kepada orang tua diharapkan dapat menerapkan pola asuh yang tepat kepada anaknya sehingga anak tidak merasa kekurangan perhatian atau kasih sayang. Dengan penerapan pola asuh yang tepat maka pendidikan keluarga yang akan menjadi landasan atau dasar dalam memberikan pengalaman langsung kepada anak, sebelum anakanak terjun ke lingkungan sekolah dia harus mengetahui terlebih dahulu lingkungan keluarganya sendiri. (2) Kepada Guru-guru di sekolah dasar dapat memberikan kegiatan pembelajaran yang lebih menekankan tentang pembelajaran langsung agar peserta didik lebih mudah mengerti. (3) Kepada peneliti lain dapat mengembangkan penelitian ini dengan mengaitkan mata pelajaran lain, metode, dan model pembelajaran yang lainnya, sehingga nantinya dapat menambah wawasan mengenai penerapan pola pengasuhan orang tua guna untuk mencapai hasil belajar yang maksimal.

\section{Daftar Pustaka}

Agustiana, I Gusti dan Nyoman Tika. 2013. Konsep Dasar IPA. Yogyakarta: Penerbit Ombak.

Amir, dkk. 2019. "Pengaruh Model Problem Based Learning dan Pola Asuh Orang Tua Terhadap Keterampilan Proses Sains Peserta Didik Mts". Jurnal Biofiskim. Vol. 1, No.1.

Anggraini, dkk. 2017. "Hubungan Pola Asuh Orang Tua Dengan Kepribadian Siswa SMA di Kota Bengkulu”. Jurnal Ilmiah Bimbingan dan Konseling. Vol.1, No.1.

Budang, Pinsesius. 2017. "Korelasi Pola Asuh Orang Tua Dengan Hasil Belajar Matematika Pada Siswa Kelas IV SD Negeri 5 Tengadak". Jurnal Pendidikan Dasar PerKhasa. Vol.3, No.2.

Fitasari, Putu dkk. 2019. "Pengaruh Pola Asuh Orang Tua Terhdap Hasil Belajar Matematika dengan Efikasi Diri Sebagai Intervening". International Journal of Elementary Education. Vol. 3, No.4.

Juniarti, Ni Komang dkk. 2020. "Hubungan Antara Pola Asuh Orang Tua dan Konsep Diri dengan Kompetensi Pengetahuan Matematika Siswa". Jurnal ilmiah Sekolah Dasar. Vol.4, No.1. 
Lestari, Sri. 2012. Psikologi Keluarga. Jakarta: Kencana.

Nurhamidah, Gima dkk. 2019. "Penerapan Model TS-TS Untuk Meningkatkan Aktivitas dan Hasil Belajar Siswa Sekolah Dasar". Jurnal Mimbar PGSD Universitas Pendidikan Ganesha. Vol. 1, No.2

Pucangan, Ketut dkk. 2017. "Hubungan Antara Konsep Diri Dan Pola Asuh Orang Tua Terhadap Hasil Belajar SD Kelas II". Jurnal Mimbar PGSD Universitas Pendidikan Ganesha. Vol. 5, No.2.

Santi, dkk. 2020. "Hubungan Pola Asuh Orang Tua Dan Kecerdasan Interpersonal Dengan Penguasaan Kompetensi Pengetahuan IPS Siswa Kelas IV". Jurnal Pemikiran dan Pengembangan Sekolah Dasar. Vol 7, No.2.

Sugiartini, Ketut dkk. 2017. "Hubungan Pola Asuh Orang Tua dan Rasa Percaya Diri Terhadap Hasil Belajar IPA Kelas V". Jurnal Mimbar PGSD Universitas Pendidikan Ganesha. Vol. 5, No.2.

Susanto, Ahmad. 2013. "Teori Belajar dan Pembelajaran”. Jakarta: Kencana.

Susanto, Dedy. 2019. “Anakku Hartaku”. Jakarta: PT Gramedia Pustaka Utama.

Wibowo, Agus. 2012. "Pendidikan Karakter Strategi Membangun Karakter Bangsa Berperadaban". Yogyakarta: Pustaka Pelajar.

Widhiasih, Ika dkk. 2017. "Pengaruh Pola Asuh Orang Tua Terhadap Hasil Belajar IPS". Jurnal Kreatif. Vol 7, No.2. 